\begin{tabular}{c|c|c}
\hline Jurnal Penelitian Farmasi Herbal & Vol. 2 No. 1 & Edition: May - October 2019 \\
\hline & http://ejournal.delihusada.ac.id/index.php/JPFH & \\
\cline { 2 - 3 } Received: 04 Augustus 2019 & Revised: 01 October 2019 & Accepted: 12 October 2019
\end{tabular}

\title{
FORMULASI DAN EVALUAI STABILITAS FISIK PATCH TRANSDERMAL ALKALOID NIKOTIN DAUN TEMBAKAU (Nicotiana tobacum Linn) DENGAN VARIASI POLIMER DAN ASAM OLEAT
}

\author{
Adi Nurmesa, Nurhabibah, Aji Najihudin \\ Universitas Garut, Jl. Jati No 33, Kec Tarogong Kaler, Jawa Barat \\ Email: adi.nurmesa96@gmail.com
}

\begin{abstract}
Research on the tobacco leaves nicotine alkaloid (Nicotiana tobacum L) transdermal patch formulation has been carried out as a cigarette dependence therapy with variations in polymers and oleic acid as a penetration enhancer. The purpose of this study is to formulate a stable transdermal patch of nicotine alkaloid tobacco leaf and to see the effect of adding cellulose, PVP and oleic acid to the release of nicotine in vitro. Transdermal patch formulation consists of nicotine alkaloid tobacco leaf, PVP, ethyl cellulose, PVP, PEG 400, propylenglycol and oleic acid. In this study, 3 formulas were made with concentration variants of PVP: EC namely $F 1=1: 1$, $F 2=1: 2$, and $F 3=1: 3$, where the variations in penetration enhancements in the form of oleic acid were F1: 0.10, F2: 0.15, and F3: 0.20. Evaluation of transdermal patch preparations includes organoleptic, matrix weight test, matrix thickness test, drying shrinkage percentage, moisture uptake, matrix fold resistance test, skin irritation test, patch matrix surface $\mathrm{pH}$ test, elongation percentage, frezee and thaw test, nicotine content test, and nicotine release (diffusion cell) test, based on physical stability test of all relatively stable transdermal patch formulas and kinetics of transdermal patch release kinetics following first order and the results of statistical analysis using Variant Analysis (ANOVA) showed differences in F1, F2 and F3, and based on the Korsmayer Peppas test following the non-fick law
\end{abstract}

Keywords: nicotine transdermal patch, tobacco leaves, PVP, ethyl cellulose, oleic acid

\section{PENDAhULUAN}

Rokok adalah salah satu jenis produk yang paling populer yang terbuat dari bahan baku tembakau (tobacco). Tembakau merupakan ekstrak organik dari daun tumbuhan yang termasuk dalam genus Nicotiana dan famili Solanaceae (famili untuk tumbuhan tomat dan kentang), Komponen yang paling banyak adalah nikotin. Tar, nikotin dan karbon monoksida merupakan tiga macam bahan kimia yang paling berbahaya dalam asap rokok. Tar adalah kumpulan dari beribu-ribu bahan kimia dalam komponen padat asap rokok dan bersifat karsinogenik (Kussuma, 2012).

Pada saat rokok diisap, tar masuk kerongga mulut sebagai uap padat yang setelah dingin akan menjadi padat dan membentuk endapan yang berwarna coklat pada permukaan gigi, saluran napas, dan paru-paru. Komponen tar mengandung radikal bebas, yang berhubungan dengan resiko timbulnya kanker (Kussuma, 2012). Nikotin merupakan bahan yang bersifat toksik dan dapat menimbulkan ketergantungan psikis. Nikotin merupakan alkaloid alam yang bersifat toksis yang berbentuk cairan, tidak berwarna, dan mudah menguap. Zat ini dapat merubah warna menjadi coklat dan berbau seperti tembakau jika bersentuhan dengan udara. Nikotin berperan dalam menghambat perlekatan dan pertumbuhan sel fibroblast ligamen periodontal, menurunkan isi protein fibroblast, serta dapat merusak sel membran. Ketergantungan dengan nikotin dapat penyebabkan depresi (Horwood, 2010).

Rokok mengandung banyak bahan kimia. Setiap satu batang rokok dibakar, mengeluarkan sekitar 4.000 bahan kimia diantaranya adalah nikotin, gas, karbon monoksida, nitrogen oksida, 
hidrogen sianida, ammonia, akrolein, benzene, dan etanol. Kandungan rokok sangat berbahaya bagi perokok maupun orang sekitarnya. Asap rokok yang terhirup dapat menyebabkan penyakit berbahaya, yaitu kanker,penyakit jantung dan emfisema. Pada organ reproduksi akan menyebabkan gangguan seperti kemandulan (pria dan wanita), impotensi, gangguan kehamilan dan perkembangan janin (Sari, 2010).

Kebiasaan merokok juga membawa pengaruh buruk terhadap kebiasaan (habits) para individu, akan tetapi tidak berpengaruh erat dengan pembentukan kepribadian seseorang. Sifat rokok yang menyebabkan kecanduan (adiktif) secara permanen yang menyebabkan kebiasaan merokok menjadi sesuatu yang sangat sulit untuk dihilangkan Kebiasaan ini sangat merugikan kesehatan orang lain karena menjadikan orang lain sebagai perokok pasif yang jauh lebih berbahaya dibandingkan dengan perokok aktif. Resiko terkena penyakit lebih besar pada perokok pasif karena mereka tidak mempunyai filter dalam menyerap seluruh asap rokok yang dikeluarkan perokok aktif (Nururahmah, 2014).

Kebiasan merokok harusnya dapat dikurangi dengan beberapa terapi salah satunya adalah terapi dengan menggunakan patch yang mengandung nikotin dosis rendah secara terus menerus sediaan ini sering disebut dengan NRT (Nicotin Replacement Therapy), tujuan dari NRT adalah kadar nikotin hampir konstan untuk menurunkan gejala withdrawal pada smoking cessation. NRT melepaskan nikotin ke dalam darah secara perlahan tidak memberikan kadar nikotin yang mendadak tinggi seperti nikotin pada rokok, sehingga potensi adiksinya minimal (Sadikin, 2008).

Patch transdermal merupakan sediaan drug delivery system yang berupa patch dengan perekat yang mengandung senyawa obat yang diletakan dikulit untuk melepaskan zat aktif dalam dosis tertentu melalui kulit menuju aliran darah, sediaan dalam bentuk patch transdermal dapat memberikan pelepasan yang terkendali ke dalam tubuh pasien (Sadikin, 2008). Pada penelitian ini dibuat patch transdermal dengan ekstrak etanol daun tembakau dengan menggunakan dua polimer yaitu polimer hidrolifilik (PVP) dan polimer hidrofobik (ctil cellulosa) serta asam oleat sebagai peningkat penetrasi, etil cellulosa dan PVP pada sediaan patch berpengaruh untuk menghantarkan zat aktif yang terkandung dalam ekstrak etanol daun tembakau, penggunaan etil cellulosa menyebabkan terbentuknya barier sehingga bahan aktif terjebak dalam sediaan yang mengakibatkan bahan aktif tidak mudah dilepaskan dari basisnya sedangkan PVP menyebabkan terbentuknya poripori sehingga perlu dikombinasikan antara polimer PVP dan etil cellulosa, sedangkan asam oleat sebagai peningkat penetrasi zat aktif sehingga didapatkan dosis yang optimal dari patch transdermal ekstrak etanol daun tembakau di dalam peredaran darah (Rachmawati, 2015)

Tujuan dari penelitian ini adalah untuk menformulasikan patch transdermal ekstrak daun tembakau dimana zat aktif berupa ekstrak memiliki kelebihan jika di formulasikan menjadi patch transdermal yaitu dapat mengurangi iritasi penggunaan dan dapat memperbaiki sifat terapi dari NRT dimana jika dalam kondisi ekstrak dapat memberikan dosis yang kecil secara terus menerus dan kostan, formulasi patch transdermal dilakukan dengan variasi polimer pada optimasi formula basis kemudian dilakukan variasi asam oleat sebagai peningkat penetrasi zat aktif, dan kemudian diuji kestabilan fisik dan diuji secara in vitro dari patch transdermal. Penelitian ini diharapkan menjadi sumber informasi tentang formulasi patch transdermal ekstrak daun tembakau dengan penambahan asam oleat sebagai peningkat penetrasi yang kemudian dapat kembangkan pada penelitian selanjutnya

\section{METODE}

Sebagai persiapan awal dilakukan pengumpulan bahan yaitu daun tembakau (Nicotiana tobacum Linn) yang diperoleh dari kecamatan Tarogong Kaler kabupaten Garut, kemudian dideterminasi di Herbarium Bandungense, Sekolah Ilmu dan Teknologi Hayati, Institut Teknologi Bandung. Setelah pengumpulan daun tembakau (Nicotiana tobacum Linn) kemudian dilakukan pengolahan bahan, pemeriksaan karakteristik simplisia, penapisan fitokimia dan pembuatan ekstrak. Dengan menggunakan ekstraksi alkaloid yaitu dengan mengkstrak daun tembakau (Nicotiana tobacum Linn) polar (etanol) kemudian diasamkan denfgan 
$\mathrm{H}_{2} \mathrm{SO}_{4} 2 \mathrm{M}$ setelah itui di fraksinansi dengan $\mathrm{n}$ Heksan sebanyak $3 \times$ lalu dibasahkan dengan $\mathrm{NH}_{4} \mathrm{OH}$ dan fraksinasi dengann Heksan lagi sebanyak 3 x lalu diambil fase bawahnya dan dipekatkan sehingga didapatkan alkaloid nikotin, kemudian hasil ekstraksi tersebut dievaporasi sehingga diperoleh ekstrak kental daun tembakau (Nicotiana tobacum Linn).

Tahap selanjutnya yaitu penentuan basis patch transdermal dengan berbagai konsentrasi Polimer Hidrofilik (PVP), Polimer Hidrofobik (Etil Cellulosa) Kemudian dilakukan pengujian terhadap basis patch transderma/ untuk memperoleh matriks yang stabil. Setelah itu dilanjutkan dengan pembuatan sediaan patch transdermal yang mengandung ekstrak etanol daun tembakau dilakukan formulasi dengan berbagai konsentrasi asam oleat.

Kemudian dilakukan evaluasi sediaan patch transderma/meliputi uji bobot matrik, uji ketebalan matrik, persentase susut pengeringan, uji ketahanan lipatan matrik, uji iritasi kulit, uji $\mathrm{pH}$ permukaan matrik patch, persentase pemanjangan, persentase uji higroskopis, uji frezee and thaw, uji pelepasan (sel difusi), dan uji kandungan nikotin.

Tabel 3.1. Uji Kandungan Nikotin

\begin{tabular}{|l|l|c|c|c|}
\hline \multicolumn{1}{|c|}{ Komposisi (\% b/b) } & \multicolumn{1}{c|}{ Fungsi } & Formula 1 & Formula 2 & Formula 3 \\
\hline $\begin{array}{l}\text { Ekstrak Alkaloid daun } \\
\text { tembakau }\end{array}$ & Zat Aktif & $10 \mathrm{mg}$ & $10 \mathrm{mg}$ & $10 \mathrm{mg}$ \\
\hline PVP & Polimer Hidrofilik & 18 & 12 & 9 \\
\hline Etil Cellulosa & Polimer Hidrofobik & 18 & 24 & 27 \\
\hline Propilen glikol & Konsolven & 30 & 30 & 30 \\
\hline PEG 400 & Plastizer & 30 & 30 & 30 \\
\hline Asam Oleat & Peningkat penetrasi & 0,10 & 0,15 & 0,20 \\
\hline
\end{tabular}

*Bobot Patch sebanyak 500 mg

*Jumlah polimer $36 \%$

\section{HASIL DAN PEMBAHASAN}

Pada penelitian ini tanaman uji yang digunakan adalah daun tembakau yang diperoleh dari Kecamatan Tarogong Kaler, Kabupaten Garut, Jawa Barat. Tanaman tersebut dilakukan determinasi tanaman untuk memastikan kebenaran dari daun tembakau hasil determinasi menyatakan bahwa benar daun tembakau adalah Nicotiana tobacum.

Pemeriksaan karakteristik simplisia daun tembakau bertujuan untuk menentukan standar mutu simplisia sehingga layak digunakan. Daun tembakau memilki kadar abu total, kadar abu tidak larut asam, kadar abu tidak larut air, kadar air, susut pengeringan, kadar sari larut air, dan kadar sari larut etanol berturut-turut adalah $11.61 \%$, $7.27 \%, 4.39 \%, 10.45 \%, 7.65 \%, 19.75 \%, 18.28 \%$. Berdasarkan data tersebut, kadar air dari simplisia memenuhi syarat. Menurut literatur, kadar air dalam ekstrak tidak boleh lebih dari $10 \%$. Hal ini bertujuan untuk menghindari cepatnya pertumbuhan jamur dan mikroba dalam ekstrak selama penyimpanan (Bambang, 1998). Penetapan nilai susut pengeringan simplisia dilakukan untuk memberikan batasan (rentang) tentang besarnya senyawa yang hilang pada proses pengeringan (Bambang, 1998).

Penapisan fitokimia dilakukan terhadap simplisia daun tembakau untuk mengetahui golongan senyawa metabolit sekunder yang terkandung didalam daun tembakau. Hasilnya menunjukkan bahwa simplisia daun tembakau mengandung golongan senyawa alkaloid, flavonoid, fenol dan triterpenoid. Daun tembakau yang diperoleh sebanyak $14.000 \mathrm{gr}$ disortasi untuk memisahkan antara tanaman dengan kotoran yang terdapat pada tanaman tersebut. Proses pengeringan dilakukan dilemari pengering yang bertujuan untuk meminimalisir pemanasan yang dapat merusak senyawa-senyawa yang terdapat dalam tanaman tersebut. Penghalusan dilakukan untuk memaksimalkan dalam proses ekstraksi karena semakin kecil luas permukaan maka proses ekstraksi akan semakin efektif (Bambang, 1998). Sebanyak $14.000 \mathrm{gr}$ daun tembakau diperoleh 1000 gr simplisia kering yang selanjutnya dilakukan tahap ekstraksi. 


\begin{tabular}{c|c|c}
\hline Jurnal Penelitian Farmasi Herbal & Vol. 2 No. 1 & Edition: May - October 2019 \\
\hline & http://ejournal.delihusada.ac.id/index.php/JPFH & \\
\cline { 2 - 3 } Received: 04 Augustus 2019 & Revised: 01 October 2019 & Accepted: 12 October 2019
\end{tabular}

Tahap ekstraksi terhadap simplisia daun tembakau bertujuan untuk menarik senyawa metabolit sekunder yan terkandung pada daun tembakau. Ekstraksi dilakukan dengan menggunakan ekstraksi cara dingin yaitu dengan metode maserasi. Metode ekstraksi dengan cara dingin dipilih untuk meminimalisir terjadinya pemanasan yang dapat menyebabkan kerusakan terhadap senyawa-senyawa yang tidak tahan panas. Pada teknik maserasi ini menggunakan prinsip like dissolve like dengan pelarut etanol $96 \%$. Filtrat yang diperoleh diuapkan dengan rotary evaporator pada suhu $40^{\circ} \mathrm{C}$. Suhu tersebut merupakan suhu titik dibawah titik didih etanol yang bertujuan agar komponen senyawa dalam pelarut tidak rusak terhadap suhu tinggi. Dari hasil maserasi diperoleh bobot ekstrak daun tembakau $150 \mathrm{gr}$ dengan persentase rendemen $11,23 \%$.

Ekstrak kental etanol daun tembakau selanjutnya difraksinasi dengan menggunakan pelarut non polar yaitu n-heksan dengan menggunakan corong pisah dengan sebelumnya diencerkan dengan menggunakan air, fase bawah pada corong pisah diambil kemudian diulangi sampai tiga kali sampai alkaloid nikotin dalam ekstrak kental daun tembakau benar-benar tertarik, setelah di dapatkan fase non polar berupa n-heksan daun tembakau selanjutnya ekstrak di asamkan dengan menggunakan $\mathrm{HCL}$ pekat sebanyak $300 \mathrm{ml}$ kemudian dibasakan dengan menggunakan $\mathrm{NH}_{4} \mathrm{OH}$ sampai $\mathrm{pH} 9$ dengan menggunakan indikator universal selanjutnya hasil yang didapatkan di diamkan sehingga terbentuk endapan garam alkaloid nikotin berbentuk kristal, kemudian kristal dipisahkan dengan menggunakan kertas saring. Hasil yang didapat kemudian dihitung rendemennya terhadap ekstrak kental, senyawa alkaloid adalah senyawa alami amina yang bersifat basa yang mengandung satu atau lebih atom hidrogen sebagai bagian dari sistem siklik (Harborne, 2006) Senyawa alkaloid pada tembakau adalah penentu aroma yang terkait dengan kulitas tanaman tembakau, senyawa tersebut didominasi oleh senyawa nikotin sebanyak 95\% senyawa alkaloid ain yang terdapat di tembakau adalah nornikotin dan anabasin yang juga dapat menimbulkan kecanduaan apabila dikonsumsi (Harborne, 2006).

Garam alkaloid nikotin kemudian diformulasikan dalam bentuk sediaan patch transderma/ tipe matriks yang mempunyai aktivitas sebagai penurun dosis rokok pada perokok aktif. Formulasi patch transdermal tipe matriks ini menggunakan garam alkaloid nikotin sebagai bahan aktif, dan variasi zat tambahan berupa PVP sebagai polimer hidrofilik, Etil Cellulosa sebagai polimer hidrofobik dan asam oleat sebagai peningkat penetrasi, adapun zat tambahan lainnya berupa propilenglikol sebagai konsolven, PEG 400 Sebagai platicizer.

Pada formulasi dilakukan dengan dosis garam alkaloid nikotin $10 \mathrm{mg}$ dengan pembuatan patch dengan metode pelarutan dan penguapan pelarut didapatkan matrik patch transdermal dengan ukuran $2 \times 2 \mathrm{~cm}$ denan variasi Perbandingan polimer PVP : EC yaitu $1: 1,1: 2,1: 3$ dan variasi peningkat penetrasi berupa asam oleat yaitu . matriks patch transdermal yang telah terbentuk dilakukan evaluasi fisik untuk melihat kestabilan fisik sediaan matriks patch transdermal meliputi pengamatan organoleptik, keseragaman bobot, kesragaman ukuran, pengukuran $\mathrm{pH}$, uji ketahanan lipatan, Moisture content, Moisture uptake, uji persentase pemanjangan, uji freeze thaw, uji kandungan obat, uji keamanan (iritan). Dan uji pelepasan in vitro dengan menggunakan Sel Difusi franz

Pemeriksaan organoleptik merupakan cara pengujian dengan indera manusia sebagai alat utama untuk pengukuran penerimaan terhadap produk. Pemeriksaan organoleptik meliputi warna, bau dan tekstur. Sediaan patch transdermal memiliki organoleptik, warna kuning tekstur sedikit kasar dan bau asam oleat, tekstur yang kasar dipengaruhi oleh kombinasi polimer biodegradebel (PVP) dan polimer non bioderadebel (EC), dimana setelah pelarut menguap polimer tersebut cenderung membentuk ikatan sambung silang antar polimer sehingga teksturnya sedikit kasar, sedangkan bau asam oleat dipengaruhi oleh zat tambahan berupa asam oleat sebagai peningkat penetrasi pada formula (Agoes, 2008).

Pemeriksaan keseragaman bobot bertujuan untuk mengetahui kesamaan dari bobot masing masing patch yang ditujukan untuk mengevaluasi konsistensi proses pembuatan, proses pembuatan yang baik akan menghasilkan produk yang relatif seragam yang dalam hal ini berarti memuat dosis 


\begin{tabular}{c|c|c}
\hline Jurnal Penelitian Farmasi Herbal & Vol. 2 No. 1 & Edition: May - October 2019 \\
\hline \multirow{2}{*}{ Received: 04 Augustus 2019 } & http://ejournal.delihusada.ac.id/index.php/JPFH & \\
\cline { 2 - 3 } & Revised: 01 October 2019 & Accepted: 12 October 2019
\end{tabular}

obat yang seragam dalam setiap satuan sediaan. Keserangaman dosis sangat penting dalam produksi sediaan obat, dimana bobot patch harus seragam dan tidak boleh menyimpang dari $5 \%$, hasil pemgukuran menunjukan formula 1 memilki rata rata bobot $0,5033 \mathrm{gr} \pm 0,00577$, formula 2 menunjukan keberagaman bobot $0,513 \mathrm{gr}$ $\pm 0,00577$ dan formula 3 menunjukan nilai keseragaman bobot 0,523 $\pm 0,00577$ gram hasil tersebut menunjukan keseragaman bobot memenuhi syarat dimana patch tidak memiliki penyimpangan keseragaman bobot diatas $5 \%{ }^{(28)}$

Pemeriksaan ketebalan pada patch transdermal bertujuan untuk mengetahui kesamaan dari tebal tiap-tiap patch transdermal pada masing masing formula, dimana semakin tebal patch semakin mempengaruhi daya difusi patch pada penetrasi zat aktif di dalam patch transdermal, pada formula 1 didapatkan hasil ketebalan patch $0,2116 \mathrm{~mm} \pm 0,002886$ pada formula 2 menunjukan hasil ketebalan $0,2216 \mathrm{~mm}$ $\pm 0,002886$ dan formula 3 menujukan nilai ketebalan 0,2316 $\mathrm{mm} \pm 0,002886$ dari hasil tersbut menunjukan bahwa ketebalan dari seluruh patch tiap fomula menunjukan nilai yang seragam dan tidak terlalu tipis maupun terlalu tebal, dimana jika terlalu tipis patch akan cenderung rapuh dan jika terlalu tebal akan mengganggu pada penetrasi obat kedalam tubuh (Sari, 2015).

Pemeriksaan $\mathrm{pH}$ dilakukan dengan tujuan untuk mengetahui apakah sediaan patch transdermal yang diformulasikan telah sesuai dengan $\mathrm{pH}$ kulit atau tidakPemeriksaan $\mathrm{pH}$ pada permukaan matrik patch transdermal dilakukan dengan menggunakan $\mathrm{pH}$ universal Menurut Djuanda, 2007, pH kulit berkisar antara 4,5-6,5. Apabila suatu bahan yang mengenai kulit semakin bersifat asam atau basa dapat mengiritasi kulit ${ }^{(35)}$. Hasil pengukuran uji $\mathrm{pH}$ di dapatkan seluruh $\mathrm{pH}$ formula patch memiliki $\mathrm{pH} 5$

Pemeriksaan uji kandungan lembab (Moisture content) bertujuan untuk menetahui susut pengeringan, pengurangan bobot setelah patch disimpan selama $3 \times 24$ jam di dalam desikator, sediaan patch yang dinginkan adalah mengandung sedikit air dengan rentang kurang dari 10\% (Kumar, 2012) kadar air dalam sediaan patch menunjukan patch benar benar stabil dan kering dengan nilai \% yang rendah akan melindungi patch dari cemaran atau kontaminasi mikroba (Kumar, 2012). Hasil menunjukan nilai Moisture content pada formula 1 adalah 2,58\% $\pm 1,085$, formula 2 nilai Moisture content adalah $4,44 \% \pm 0,69$ dan formula 3 nilai Moisture content adalah $4,99 \% \quad \pm 1,056$ hasil tersebut menunjukan bahwa seluruh formula memenuhi syarat nilai Moisture content yang ditentukan, dimana semakin tinggi perbandingan antara polimer hidrofilik (PVP) dan polimer hidrofobik (Etil Sellulosa) semakin tinggi pula nilai Moisture hal ini disebabkan karena polimer hidrofobik cenderung tidak menyerap air dari lingkungan. Perbedaan nilai Moisture Content tiap formual patch transdermal alkaloid nikotin dikarenakan kemampuan PVP dalam menyerap lembab di linkungan. Menurut Rowe (2009), nilai kandungan lembab PVP lebih tinggi dibandingkan Etil Sellulosa, Dimana semakin rendah nilai kandungan lembab patch mengindikasikan bahwa patch yang dihasilkan memenihi karakteristik fisik patch yang baik yakni tidak mudah patah (Micrun, 2016).

Pemeriksaan uji higroskopis atau serap kelembapan (Moisture uptake) bertujuan untuk memeriksa tingkat peyerapan air dari patch transdermal, yang dikondisikan pada bejana yang memiliki kelembapan $75 \%$ adapun ada pengaplikasikan patch pada kulit menunjukan tingkat penyerapan air oleh patch selama pengunaan (Kumar, 2012), tujuan dari pengujian ini adalah untuk mengetahui ketahananpatch terhadap kelembapan yang dimana jika patch banyak menyerap lembab akan mempengaruhi kualitas patch, yang dapat mempengaruhi elastisitas patch dan patch yang cenderung cepat robek (Nurahmanto, 2015). Hasil pengukuran menunjukan nilai moisture uptake formula 1 adalah $20,83 \% \pm 0,9006$, formula 2 menunjukan nilai Moisture uptake adalah $18,51 \% \pm 0,9122$ dan formula 3 menunjukan nilai Moisture up take adalah $10.18 \% \pm 2,7019$.

Hasil tersebut menunjukan bahwa nilai Moisture uptake dimana secara umum peningkatan persen (\%) daya serap kelembapan akan terjadi jika hidrofilitas dari polimer atau plasticizer atau enhancer juga dapat meningkatkan kandungan lembab pengujian kandungan lembab dan kemampuan daya serap lembab mengindikasikan bahwa peningkatan nilai daya serap lembab 


\begin{tabular}{c|c|c}
\hline Jurnal Penelitian Farmasi Herbal & Vol. 2 No. 1 & Edition: May - October 2019 \\
\hline & http://ejournal.delihusada.ac.id/index.php/JPFH & \\
\cline { 2 - 3 } Received: 04 Augustus 2019 & Revised: 01 October 2019 & Accepted: 12 October 2019
\end{tabular}

berkaitan dengan sifat hidroskopis polimer dan pengunaan PEG 400, dan Propilenglikol sebagai plasticizer atau pembentuk film.seluruh formula memenuhi syarat sehingga menghasilkan ketahanan patch pada lingkungan yang lembab (Micrun, 2016).

Pengujian elongation test (Persentase pemanjangan) adalah perubahan panjang maksimum yang dapat dialami bahan pada saat mengalami peregangan atau ditarik sampai sebelum bahan itu robek, perubahan panjang dapat dilihat apabila sediaan patch tersebut robek (Sahoo, 2013), hasi pengukuran menunjukan formula 1 memiliki hasil $33.33 \% \pm 0$ formula 250 $\% \pm 0$ dan formula 3 menunjukan nilai $53,3 \% \pm$ 5,77 dari hasil keseluruhan seluruh formulla memiliki nilai pemanjangan yang baik, sehingga setiap patch memiliki elastisitas dan fleksibelitas yang baik (Kumar, 2012) dimana semakin tinggi perbandingan polimer Etil Sellulosa akan menghasilkan nilai persentase pemanjangan yang baik hal ini dikarenakan etil cellulosa merupakan polimer nondegradibel yang memiliki ketahanan yang lebih dibandingkan polimer biodegradible (Agoes, 2008).

Pengujian folding endurance (uji ketahanan lipatan) bertujuan untuk mengetahui fleksibelitas dan elastisitas patch setelah dilipat pada sudut yang sama, hasil nilai folding endurance menunjukan nilai, pada formula 1 nilainya adalah 104,3 kali $\pm 1,521$ formula 2113,6 kali $\pm 1,527$ dan formula 3 adalah 119,3 kali $\pm 1,527$ hasil tersebut menunjukan setiap formula memiliki ketahanan saat di aplikasikan kekulit dan dan memililki integritas yang baik saat diaplikasikan ke kulit, pada hasil uji ketahanan lipatan menunjukan hasil yang baik hal ini dikarenakan penggunaan plasticizer yaitu PEG 400 dan juga Propilenglikol yang memiliki fungsi sebagai platicizer selain konsolven pada formula patch transdermal alkaloid nikotin dengan hal tersebut maka nilai akan meningkatkan fleksibelitas patch (Sahoo, 2013).

Pengujian freeze thaw bertujuan untuk mengetahui kestabilan fisik patchtransdermal dengan pengaruh suhu. Uji freeze thaw dilakukan sebanyak 5 siklus pada suhu $4^{\circ} \mathrm{C}$. Dan 48 jam berikutnya sediaan ditempatkan dioven pada suhu $40^{\circ} \mathrm{C}$. Pengujian freeze thaw bertujuan untuk melihat perubahan bobot akibat stres suhu
(18). adapun hasil uji Freezee thaw pada formula 1 adalah $3,793 \% \pm 0,04041$, formula 2 mempunyai hasil uji freezee thaw $3,13 \% \pm 1,10851$ dan formula 3 memiliki hasil $4,933 \% \pm 1,0692$ Hasil pemeriksaan menunjukkan tidak adanya perubahan yang terlalu setelah dilakukan 5 siklus uji Freezee thaw Hal ini menunjukkan bahwa patch transdermal tetap stabil walaupun disimpan pada suhu dingin atau suhu panas (Nirav, 2011).

Uji keamanan (iritan) sediaan dilakukan menggunakan punggung tangan responden sebanyak 10 orang. Uji dilakukan untuk mengetahui apakah sediaan patch transdermal menyebabkan reaksi seperti gatal, panas pada kulit atau kemerahan sehingga didapat hasil keamanan sediaan patch transdermal yang telah dibuat. Dari data pengujian keamanan (iritan) dapat diketahui bahwa formula patch transdermal alkaloid nikotin daun tembakau ini aman untuk digunakan dan tidak memberikan efek iritasi seperti bengkak, kemerahan dan gatal-gatal (Nirav, 2011).

Uji Pelepasan patch transdermal secara in vitro bertujuan untuk mengukur jumah obat yang dilepaskan ke dalam kompartemen tiap tiga jam sekali, pada pengujian ini digunakan sel difusi franz vertikal dengan membran berupa kulit ular dimana kulit ular memiliki kesamaan seperti stratum coerneum dimana stratum corneum inilah yan merupakan halangan utama pada pelepasan obat melalui kulit, pada hasil pengujian uji pelepasan didapatkan hasil pada formula, 1, 2 dan 3 seperti lampiran setelah di dapatkan hasil tersebut lalu ditentukan kinetika pelepasan obat yang cocok dengan membandingkan nilai regresi linier, pada zero orde, one orde higuchi, atau korsmayer peppas (Rahul, 2017), kemudian didapatkan hasil kinetika orde pelepasannya adalah mengikuti kinetika orde satu pada patch transdermal nikotin, pada orde satu merupakan model kinetika pelepasan menunjukan pelepasan yang tergantung pada konsentrasi obat selama periode tertentu apakah periode hari atau beberapa tahun dalam hal ini patch transdermal dapat melepaskan obat selama satu hari atau 24 jam.

Absorbsi obat menurut orde non zero masih efektif minimum dan maksimum yang aman. Kebanyakan obat memperlihatkan perubahan ritmik dalam bioavailabilitas, absorbsi, distribusi, 


\begin{tabular}{l|r|r}
\hline Jurnal Penelitian Farmasi Herbal & Vol. 2 No. 1 & Edition: May - October 2019 \\
\hline & http://ejournal.delihusada.ac.id/index.php/JPFH & \\
\cline { 2 - 3 } Received: 04 Augustus 2019 & Revised: 01 October 2019 & Accepted: 12 October 2019
\end{tabular}

dan eksresi sehingga pelepasan tidak selalu harusv mengikuti orde nol, bahkan kadang kadang sama sekali tidak ditentukan. Pertimbangan dalam penhantaran obat aalah konsentrasi obat dalam darah dan efek farmakologi (Agoes, 2008).

Pengujian Drug Content atau kandungan obat digunakan untuk mengetahui berapa banyak jumlah alkaloid nikotin yang dapatv terikat pada sistem polimer transdermal adapun hasilnya pada formula 1 nilai drug contentnya adalah 8,968 mg $\pm 0,0100$, formula 2 memiliki nilai drug content $9,2932 \mathrm{mg} \pm 0,0100$, dan formula 3 memiliki nilai drug content 9,3164 $\pm 0,0100$ dari hasil tersebut menunjukan dari dosis awal pembuatan sebanyak $10 \mathrm{mg}$ polimer cukup baik dapat melepaskan zat aktif dan memiliki ketersediaan yang baik pada matrik patch transdermal, hal ini dipengaruhi oleh sifat dari polimer hidrofilik yang cenderung mengikat garam alkaloid nikotin dan polimer hidrofilik yang cenderung menahan terjadinya penguapan lebih lanjut dari alkalod nikotin (Agoes, 2008).

Adapun urutan proses perjalanan suatu obat dari sediaan sistem transdermal/sifat pembentukan depot obat metabolisme dan pengambilan melalui kapiler, adapun setiap tahap dapa mengontrol sistem penghantaran secara keseluruhan, dan berkontribusi terhadap pola pelepasan obat secara menyeluruh (19). Adapun baiknya uji pelepasan pada patch transdermal alkaloid nikotin dipengaruhi oleh adanya peningkat permeasi, hal ini merupakan strategi untuk meningkatkan permeasi melalui berbagaii cara, hal ini dapat dilakukan dengan pendekatan mengunakan bahan kimia maupun fisika, adapun pada penelitian ini mengunakan asam oleat yang merupakan bahan kimia (Agoes, 2008) yang memiliki mekanisme peningkat permeasi dengan hasil uji statistik uji ANOVA Post Hoc LSD menunjukan nilai $p<0,005$ menunjukan adanya perbedaan yang signifikanpelepasan obat menurut orde satu pada formula 1, formula 2 dan formula 3 (32)

Uji Pemodelan Korsmayer peppas adalah untuk mengetahui mekanisme dari polimer dalam melepaskan obat ke dalam kompartemen adapun hasil dari uji Korsmayer peepas pada formula 1 2,0967, pada formula 2 nilai n-nya adalah 2,2506 dan formula 3 di apatkan nilai n-nya adalah 2,1786, dari hasil tersebut di dapatkan mekanisme dari pelepasan dari Patch transdemal alkaloid nikotin daun tembakau adalah non fick yang mengikuti mekanisme super case II transport dikarenakan nilai dari $\mathrm{n}$ lebih dari 1, mekanisme super case II transport adalah mekanisme pelepasan polimer yang mempunyai dua mekanisme sekalius yaitu erosi dan difusi, erosii merupakan mekanisme pelepasan polimer tidak larut air dengan ikatan yang labil.

Hidrolisis ikatan labil menyebabkan putusnya kerangka polimer sehingga terbentuk molekul berbobot molekul rendah dan molekul yang lebih larut air mekanisme tersebut dalam formulasi patch transdermal dipengaruhi oleh zat tambahan berupa etil cellulosa, sedangkan polimer PVP yang memiliki sifat hidrofilik memiliki mekanisme transport difusi mekanismenya itu dengan proses pemindahan massa individual molekul zat yang larut melalui membran yang dibawa oleh gerakan acak molekul dan yang memisahkan fase mekanismenya dapat melalui mekanisme transport aktif, pasif dan transport terfasilitasi dalam hal ini patch transdema/ memiliki difusiterfasilitasi dengan adanya peningkat penetrasi berupa asam oleat (Agoes, 2008).

Sifat Aliran atau Fluks pada patch transdermal alkaloid nikotin pada formula 1, 2 dan 3 cenderung memiiki aliran yang baik atau $J$ Fluks yang baik hal ini di pengaruhi oleh kombinasi polimer yang berdifusi melalui stratum coerneum secara baik sehinga menghasilkan ketersediaan yang baik pada kompartemen tujuan dari pengujia ini adalah untuk mengetahui jumlah obat yan dilepaskan pada media kompartemen sel difusi franz dibandingkan diameter membran penghalang (kulit ular) sehinga di dapatkan hasil fluks aliran obat yang dilepaskan selama 24 jam pengujian sel difusi franz vertikal (Rahul, 2017).

Adapun kombinasi antara polimer hidrofilik dan hidrofobik dapat mempengaruhi pemeasi obat di dalam kulit dengan mekanisme suatu lapisan material polimer nonbiodegradeble (Etil Sellulosa) mengelilingi ini setempat obat berdifusi secara perlahan lahan dengan bantuan polimer hidrofiik (PVP) membuka pori pori pada lapisan kulit sehinga kombinasi keduanya bersifat sinergis (Ameliana, 2013). 


\begin{tabular}{|c|c|c|}
\hline Jurnal Penelitian Farmasi Herbal & Vol. 2 No. 1 & Edition: May - October 2019 \\
\hline & http://ejournal.delihusada.ac.id/index.php/JPFH & \\
\hline Received: 04 Augustus 2019 & Revised: 01 October 2019 & Accepted: 12 October 2019 \\
\hline
\end{tabular}

\section{SIMPULAN}

Berdasarkan uji stabilitas fisik pada sediaan patch transdermal, semua formula uji relatif stabil. Berdasarkan pengujian pelepasan obat pada sediaan patch transdermalekstrak alkaloid daun tembakau mengikuti kinetika pelepasan orde 1 dan pada hasil uji ANOVA Post Hoc LSD memiliki nilai $p=0,000$ yang artinya adanya perbedaan signifikan pada uj pelepasan Formula 1, Formula 2 dan Formula 3

\section{DAFTAR PUSTAKA}

Kusumma, A.R.P. 2012, Pengaruh Merokok Terhadap Kesehatan Gigi dan Rongga Mulut. Kedokteran Gigi, Universitas Islam Sultan Agung. Diakses tanggal 22 April 2017 http://unisulla.ac.id/newver/images/jurnal/a ndina\%20

Horwood, L.J., Boden J.M., dan David, 2010, Cigaratte Smoking and Depression Test of Cause Linkages Using a Longitudinal Birth Cohort. The Britsh Journal of Psychiatry Diakses http://bjp.rcpsych.org/content/196/6/440full .pdf+html Diakses tanggal 22 April 2017

Sari, W. Fitriani, Eriani, K. 2010. The Effect of Cigarettes Smoke Exposured Cause Fertility. Jurusan Biologi MIPA Unsyiah Banda Aceh. http://isjd.pdii.lipi.go.id/admisi/jurnal/5okt08 08.pdf Diakses tanggal 22 April 2017

Nururahmah. 2014. Pengaruh Rokok Terhadap Kesehatan dan Pembentukan Karakter Manusia, (Prosing Seminar Ilmiah) Universitas Cokroaminoto, Palopo.

Sadikin, D.Z. dan Louisa, Melva., 2008, Program Berhenti Merokok, Departemen Farmakologi dan Terapeutik Fakultas Kedokteran Universitas Indonesia, Jakarta

Rachmawati, Dhitya Sagita. 2015, Optimasi Polietilen Glikol Dan Polivinil Pirolidon Terhadap Laju Pelepasan Dan Uji Moesture Content Patch Ibuprofen, Universitas Jember, Jember.

Bambang, C. 1998. Tembakau Budidaya dan Analisis Usaha Tani, Penerbit Kanisius, Yogyakarta

Agoes, G., 2008, Sistem Penghantaran Obat Pelepasan Terkendali, Penerbit ITB, Bandung
Rowe, R.C, Sheskey, P.J., et.al. 2009, Handbook of Pharmaceutical Excipients. American Pharmaceutical Asociation. Inc.

Harborne, J.B. 2006, Metode Fitokimua Penuntun, Cara Modren Menganalisis Tumbuhan. Penerbit ITB, Bandung

Ameliana, L, 2013, Pengembangan Sediaan Transdermal Patch Meloxicam Tipe Matriks Dalam Beberapa Kombinasi Polimer, Universitas Jember, Jember.

Micrun, N, Andi, N., Nuru, A.Y., Nur, A.K. 2016, Formulasi Patch Kosmetik Lendir Bekicot (Achantina fulica) Dengan Polimer Kitosan Dan Berbagai Variasi Amilum, STIF dan AKAFARMA Kebangsaan, Makassar

Sari, Purwita, Dian, 2015, Formulasi Patch Amoxicilin dengan Kombinasi HPMC dan PVP Sebagai pendekatan Penanganan Sariawan, UMY, Yogyakarta.

Kumar, S.D., Sairan, R., Anandadabu, S., Karpagavalii., Maheswara, A., dan Narayanan, N., 2012., Formulation and Evauation Transdermal Patchs of Salbutamol. Res. Jour. Phar. Bio. Chem. Sci. Vol. 3: 1132-1139

Sahoo, Kumar Biraj., dan Amlya Kenta Mishra, 2013, Formulation and Evaluation of Transdermal Patches of Diclofenac. Departement of Pharmaceutics, Collage Of Pharmaceutical Science Marine Drive Road Puri, Odisha, India

Nirav, S., Sheth dan Rajan B Mistry, 2011, Formulation and Evalution of Transdermal Patches and to Study Permeation Enhancerments effect of eugenol. Jour. of Applied Pharm. Scien.

Nurahmanto, Dwi, 2015, Formulasi dan Evaluasi Sediaan Patch Transdermal Prometazin HCL sebagai Pengobatan Morning Sickness, Universitas Jember, Jember

Rahul Shivajiro Solunke dan Praveen, D, Chaudhari, 2017, Formulation and Evaluation of Repaglinide Patches For Transdermal Drug Delevery. Int. Jour. of Pharm. and Bio. Scie. 